\title{
The Conflicts Between Henchard and Farfrae in the Mayor of Casterbridge
}

\author{
Qin Liu \\ School of Foreign Language, Yancheng Normal University, Yancheng, China \\ Email address: \\ hobbyc@163.com \\ To cite this article: \\ Qin Liu. The Conflicts Between Henchard and Farfrae in the Mayor of Casterbridge. International Journal of Applied Linguistics and \\ Translation. Vol. 3, No. 3, 2017 pp. 40-45. doi: 10.11648/j.ijalt.20170303.12
}

Received: May 29, 2017; Accepted: July 3, 2017; Published: August 3, 2017

\begin{abstract}
The Mayor of Casterbridge is one of the most successful novels of Thomas Hardy, who is a famous English writer in the later part of the Victorian age. The Mayor of Casterbridge has been a very controversial novel since its publication. Critics all over the world have done lots of pieces of researchin revealing its theme, analyzing its characters and exploring its writing techniques. But very few researchers focus on the differences between the two mayors of Casterbridge. This paper intends make an all-round exploration on the conflicts between Henchard and Farfrae in the novel. Henchard and Farfrae, the two mayors of Casterbridge, have very different destinies due to their distinct characteristic. Henchard is a man from the old; he stands for the old and outdated force. It is evitable that Henchard, the old mayor, a representative from the old world will be replaced by Farfrae, the new mayor who symbolizes the new force and the new world. Two pairs of contrasts, tradition versus modernization and stubbornness versus flexibility, are discussed in details in the paper.
\end{abstract}

Keywords: Conflict, Tradition, Modernization, Stubbornness, Flexibility

\section{Introduction}

The Mayor of Casterbridge is a masterpiece of Thomas Hardy. Since the publication of the novel, it has never ceased to draw attention from the researchers. Firstly, many critics attach much importance to its theme, D. H. Fussel studied the novel about the theme of the change [1], changes from the agricultural society to the industrial world, Dale Kramer conducted researches on the protagonist's character [2], especially the failure of Henchard and his character flaws. Fredric R. Karl studied the character of Henchard, he believed "the events that help nullify Henchard are those that develop from his own character: he literally makes the world that first envelops and then squeezes him to death" [3]. Secondly, some critics focused on the archetype of the novel, Julian Moynahan made a comparative study on the archetypes of Henchard and Farfrae in The Mayor of Casterbridge and the Old Testment First Book of Samuel A study of literary Relationships [4]. Thirdly, some reviewers discuss the artistic techniques of the novel. Up to now, very few researches focus on the conflicts between the two mayors of Casterbridge, which is the focus of this paper. In the novel, Hardy presented two different mayors of Casterbridge. Henchard is the old mayor, traditional and stubborn, he rises to the mayor of the town from a poor hay-trusser, he is ambitious and successful, but he cannot forget about his sinful past, and he keeps punishing himself for selling his wife and child when he is drunk. And finally his business and his life are ruined because of his stubbornness and traditional way of dealing with everything. Farfrae, the new mayor, modern and flexible and successful businessman replaces Henchard in the end of the novel. He is so rational that he never does anything without second thoughts, everything he has done is in accordance with the laws of business, and he is the striking contrast to Henchard.

\section{Tradition Versus Modernization}

In the middle eighteenth century, the Great Britan went through the industrial revolution, which greatly influenced the British society, and changed people's life and minds. The English bourgeoisie prospered and became dominant in the society while the traditional feudal class declined and lost the leading position [5]. And due to the industrial revolution, the center of Britain changes from South to North, the once prosperous South declined and the North became important and developed because of their large amount of raw materials 
and cheap labour. The agricultural South faded especially after the repealing of the Corn Law in 1846. The Mayor of Casterbridge was created during this period, and it vividly reflects the striking difference between South and North, which is the contrast between tradition and modernization.

The best representatives of the contrast between traditionand modern, the south and the north, are Henchard and Farfrae. The setting of the novel is in Casterbridge, a remote northerntown, Farfrae comes from a far away place, somewhere in the north, as the name suggests. Henchard was brought up in the backward of south and he became the mayor of Casterbridge, he was the backward force in the novel who was unwilling to accept the new changes in the society, and sticked to his own old-fashioned way of life, whereas, Farfrae was a young man came from the developed south who was energetic and capable of challenging the old customs. He was innovative and was always ready to implement any new thoughts and inventions, he can adapt to the new environment very willingly. The contrast between Henchard and Farfrae is the best manifestation of the conflicts between tradition and modernization.

\subsection{The Contrast in Business}

Henchard was traditional and old fashioned in dealing with the business. He adhered to old way of dealing with business; he did not have any knowledge of science and objected to any new inventions. He based his judgment on a weather prophet, Mr. Fall, when he wanted to defeat Farfrae in business [7]. He suffered a lot because of this ridiculous and foolish judgment which lead to his bankruptcy. "Henchard had backed bad weather, and apparently lost. He had mistaken the turn of the flood for the turn of the ebb. His dealings had been so extensive that settlement could not long be postponed, and to settle, he was obliged to sell off corn that he had bought a few weeks before at figures higher by many shillings a quarter. Much of the corn he had never seen; it had not even been moved from the ricks in which it lay stacked miles away. Thus he lost heavily" [6] (146). This is the vivid description of Henchard's lost in the novel. His complete downfall in the business was inevitable because of his lack of any scientific knowledge. He based his business judgment only on the words of a weather prophet who knew nothing about scientific way of forecasting the weather, he only predicted the weather in a superstitious way, which is absolute nonsense. Henchard behaved incautiously and unreasonably. As a businessman, he did not even see the corn, and he did not care about the quality of the corn and the market, he dealt the business impulsively and incautiously. Henchard's belief in Mr. Fall is the disaster and complete "fall" for him.

Henchard deals his business in a backward way, everything about the business depended on his memory and all bargains were made by tongue only. Hardy gave a vivid description of the backward way of dealing with business in the novel. "His accounts were like bramble wood when Mr. Farfrae came. He used to reckon his sacks by chalk strokes all in a row like garden-palings, measure his ricks by stretching with a curse" [6] (82). Being lack of scientific management leads to his fall in business.

Henchard favors the old agricultural way of production, and he is indifferent to and rejects any new-fashioned agricultural implements as a representative of the backward agricultural world. He is unwilling to accept the new trends, and satisfies with the old backward life. He is doomed to fail in the modern world [8].

Farfrae is in striking contrast to Henchard in dealing with business, he stands for modernization. He is willing to adopt the scientifical way of business management. After becoming the manager for Henchard, Farfrae replaced the backward management with the new and scientific way. "Meanwhile the great corn and hay traffic conducted by Henchard throve under the management of Donald Farfrae as it had never thriven before. It had formerly moved in jolts; now it went on oiled casters. The old crude viva voce system of Henchard, in which everything depended upon his memoryand bargains were made by the tongue alone was swept away. Letters and ledgers took the place of 'I'll do't' and 'you shall hae't'; and, as in all such cases of advance, the rugged picturesqueness of the old method disappeared with its conveniences" [6] (69).

Farfrae would never believe the nonsense told by any weather prophet, he would never base his business judgments on any foolish ideas. He has a good knowledge of science. All the business decisions he makes would be based only on the complete analysis of market and product. He would only buy the produce of good quality at a reasonable price, and he would never suffer a lot because of the thorough analysis of the market and product. And he would earn a great deal if the market turns good. No wander he can prosper in the business world and be successful. As described in the novel, "he had purchased in so depressed a market that the present moderare stiffness of prices was sufficient to pile for him a large heap of gold, where a little one had been" [6] (148).

Farfrae is a modern man coming from the new world and is willing to, and also able to adapt to the new trends. He actively promotes the advanced new machines as well as the scientific management in dealing with the business. Farfrae speaks highly of the new advanced machines and believes that they will revolutionize the agricultural. As described in the novel "it will revolutionize sowing hereabout! No more sowers flinging their seed about broadcast, so that some falls by the wayside and some among thorns, and all that. Each grain will go straight to its intended place, and nowhere else whatever" [6] (131). Farfrae enthusiastically welcomes the new inventions, and he constantly brings new things to the backward Casterbridge, which makes him both popular and successful.

\subsection{The Contrast in Holding Entertainments}

Henchard and Farfrae are two different people, and their different ways of holding the entertainments are the best manifestation of the contrast between tradition and modernization [9].

Henchard holds the entertainment in an old-fashioned way. First, he is traditional in choosing the location of the entertainment. As described in the novel, "Close to the town 
was an elevated green spot surrounded by an ancient square earthwork---earthworks square and not square, were as common as blackberries hereabout---a spot where on the Casterbridge people usually held any kind of merry-making, meeting, or ship-fair that required more space than the streets could afford. On one side it sloped to the river Froom, and from any point a view was obtained of the country round for many miles. This pleasant upland was to be the scene of Henchard's exploit" [6] (80). From these descriptions, it can be concluded that the location of Henchard's entertainment is endowed with traditional characteristics, and it is impossible for Henchard to choose anywhere special and modern because of his traditional upbringing. The place for the entertainment was the usual and common place for the people of Casterbridge, there is nothing special for the entertainment.

Secondly, Henchard's ways of entertaining the guest is also traditional in the novel. "He advertised about the town, in long posters of a pink color, that games of all sorts would take place here; and set to work a little battalion of men under his own eye. They erected greasy-poles for climbing, with smoked hams and local cheeses at the top. They placed hurdles in rows for jumping over; across the river they laid a splippery pole, with a live pig of the neighborhood tied at the other end, to become the property of the man. There were also provided wheelbarrows for racing, donkeys for the same, a stage for boxing, wrestling, and drawing blood generally; sacks for jumping in. moreover, not forgetting his principles, Henchard provided a mammoth tea, of which everybody who lived in the borough was invited to partake without payment. The tables were laid parallel with the inner slope of the rampart, and awnings were stretched overhead." All the activities Henchard can think of are outmoded and dull which are the common occurrences of entertainments for the people in Casterbridge. As a man comes from the old, Henchard can only hold the entertainment in the old and traditional way, and he has no idea to hold a new style of entertainment [10]. He thinks that he is well prepared for the entertainment but he fails to take weather into consideration, because he thinks weather can not be predicted in the trational way, and it can only be solved by science which he is bad at. It never occurred to him that the open air entertainment would be ruined by the sudden change of weather; the bad result of the entertainment is mainly because of the traditional way of holding the entertainment.

On the contrary, Farfrae is rather modern in holding the entertainment. First, he takes weather into consideration when he makes preparations for the entertainment, although Farfrae can not know and predict the weather, he is scientific, and make scientific preparations for the problems he may encounter during the entertainment. Under the protection of waterproof cloth, the ball held in the tent is rather successful and novel to the people in Casterbridge. Secondly, (Thirdly??) the place of the entertainment is rather modern, although its appearance is unattractive to Henchard. As described in the novel, "the notes of a stringed band came from the enclosure that Farfrae had erected - the pavilion as he called it - and when the Mayor reached it he perceived that a gigantic tent had been ingeniously constructed without poles or ropes. The densest point of the avenue of sycamores had been selected, where the boughs made a closely interlaced vault overhead; to these bought the canvas had been hung, and a barrel roof was the result. The end towards the wind was enclosed, the other end was open. Henchard went round and saw the interior. In form it was like the nave of a cathedral with one gable removed, but the scene within was anything but devotional. A reel or fling of some sort was in progress; and the usually sedate Farfrae was in the midst of the other dancers in the costume of a wild Highlander, flinging himself about and spinning to the tune." Although the people in Casterbridge lived their life in a traditional, they welcomed the fresh air coming to their life, and they were willing to pay the money to attend the activities hold by Farfrae. And Farfrae was a modern businessman, business is very important to him, and everything was about the business, and everything he did was for money. The main purpose of holding the entertainment was to raise his social status, and enlarge his influences. The entertainment was very successful, Farfrae's popularity increased rapidly in Casterbridge, while Henchard's prestige decreased after his unsuccessful entertainment.

\section{Stubborn Versus Flexible}

Stubbornness is the distinctive feature of Henchard. His stubborn persistence makes him a successful businessman, and at the same time, his failure can also be attributed to this character.

\subsection{Henchard's Stubborn Persistence}

A persuasive example showing Henchard's stubbornness is his insistence in punishing himself after commiting the evil deed of selling his wife and daughter. Firstly, he made an oath not to touch any strong alcohol for the next twenty one years. We can feel his determination through his swear in the church. "He knelt upon the footpace. Dropping his head upon the clamped book which lay on the Communion-table, he said aloud---'I, Michal Henchard, on this morning of the sixteenth of September, do take an oath before God here in this solemn place that I will avoid all strong liquors for the space of twenty-one years to come, being a year for every year that I have lived. And this I swear upon the book befor me; and may I be strook dumb, blind, andhelpness?, if I break this my oath!' when he had said it and kissed the big book, the hay-trusser arose, and seemed relieved at having made a start in a new direction" [6] (19). For an alcoholic, it needs a lot of courage and determination to quit alcohol. And for a businessman, it is almost impossible, but Henchard sticks to his oath persistently and stubbornly accept the punishment for selling his wife and child. This wins him the respect and forgiveness from his wife, Susan.

Moreover, Susan even doubts that Henchard might drink himself to death when the sailor "died" at sea. "To pocket her pride and search for the first husband seemed, wisely or not, the best initiatory step. He had possibly drunk himself into his tomb. But he might, on the other hand, have had too much 
sence to do so; for in her time with him he had been given to bouts only, and was not a habitual drunkard." Susan was rather shocked to find that henchard had give up drinking completely. "But Elizabeth-Jane noticed that, though this filling went on with great promptness up and down the table, nobody filled the Mayor's glass, who still drank large quantities of water from the tumbler behind the clump of crystal vessels intended for wine and spirits" [6] (40). Everyone in the town know Henchard's oath, and this wins him the respect from the people. And he is rather frank in admitting his faults, and everyone knows that he lost his wife because of drinking. "Ah, no; don't ye know him to be the celebrated abstaining worthy of that name? He scorns all tempting liquors; never touches nothing. O yes, he've strong qualities that way. I have heard tell that he sware a gospel oath in bygone times, and has bode by it ever since. So they don't press him, knowing it would be unbecoming in the face of that: for yer gospel oath is a serious thing. Another elderly man, hearing this discourse, now joined in by inquiring, 'How much longer have he got to suffer from it, Solomon Longways?' Another two years, they say. I don't know the why and the wherefore of his fixing such a time, for 'a never has told anybody. But this is exactly two calendar years longer, they say. A powerful mind to hold out so long!" [6] (41). It really needs a very powerful mind and determination to give up drinking for Henchard. It is also Henchard's stubborn punishment for himself.

Henchard really feel very guilty to sell his wife and child, and he never denies the fact that he had made a mistake even in face of all the people in Casterbridge. He stubbornly believed that he should make amends for his past wrongdoings. In remarriage, he could find happiness by marrying Lucetta, but he insisted on making compensation to Susan and his child by remarrying Susan--- a woman he never loves. The description of Henchard's preparations for his reunion with Susan shows his stubbornness. "He pressed on the preparations for his union, or rather reunion, with this pale creature in a dogged, unflinching spirit which did credit to his conscientiousness. Nobody would have conceived from his outward demeanour that there was no amatory fire or pulse of romance acting as stimulant to the bustle going on in his gaunt, great house; nothing but three large resolves---one, to make amends to his neglected Susan, another, to provide a comfortable home for Elizabeth-Jane under his paternal eye; and a third, to castigate himself with the thorns which these restitutory acts brought in their train; among them the lowering of his dignity in public opinion by marrying so comparatively humble a woman". It is evident that there are three reasons for marrying Susan, first is for making amends to Susan, second is for the love of Elizabeth, and third is for punishing himself. Henchard is willing to sacrifice his love towards Lucetta to make amends for his sinful past. On the one hand, he is a responsible husband and father; on the other hand, he is rather a ruthless lover. He stubbornly punished himself by marrying so humle a woman in front of all the people in Casterbridge.

He never denies his past wrongdoings; he chooses to stubbornly suffer from his sinful past. Even in the court, he did not used his authority as a mayor to shut the furmity woman's mouth, he did not attempt to stop the furmity woman from revealing his shameful past in public. He stubbornly chose to admit the truth of the furmity woman's story, he never stopped punishing himself even in front of his people as a mayor. Confronted with the accusations of the furmity woman, he chose to admit everything and leave the court. "'Tis a concocted story, said the clerk. 'So hold your tongue!' 'No---'tis true' The words came from Henchard.' tis as true as the light... and upon my soul it does prove that I'm no better than she! And to keep out of any temptation to treat her hard for her revenge, I'll leave her to you'" [6] (237).

Henchard is so insistent on changing Elizabeth's surname. His obstinacy in legally changing Elizabeth's surname eventually leads to his discovery in Elizabeth's true parentage and destroyed his life completely. If he had not been so stubborn in changing the surname, he would live happily with Elizabeth till the end of his life. Shortly after Susan and Elizabeth moved into his house, he urged Susan to change Elizabeth's surname. He could not let his own daughter be called "Miss Newson" sfter the sailor. "It passed as Henchard went on:" Well, so much the better. Now Susan, I want to have her called Miss Henchard---not Miss Newson. Lots o' people do it already in carelessness---it is her legal name---so it may as well be made her usual name---I don't like t'other name at all for my own flesh and blood. I'll advertise it in Casterbridge paper---that's the way they do it. She won't object" [6] (104). But to his disappointment, Elizabeth refused to change her surname because of her respect and love for Newson. Henchard is so stubborn that he never gives up his efforts to change Elizabeth's surname. After the death of Susan, Henchard finally told Elizabeth the truth, and convinced her to change her surname. But, fate plays a joke on Henchard, he found the letter Susan wrote to him before her death and knew the real parentage of Elizabeth, which is the serious blow for him, and finally destroyed all the happy future he could have by living with Elizabeth. His stubbornness destroyed all his hopes and happiness.

\subsection{Farfrae's Flexible Love}

In contrast to Henchard, Farfrae is rather flexible. He is a businessman to the core, and everything he does was for his own interests and his business. He constantly changes his attitude to Elizabeth and Lucetta because of the commercial rules and his own benefits. As a flexible young businessman, he never insists on doing anything without clear purposes.

Farfrae uses his intelligence to handle his relationship with everyone, including the women he loves; he never allows emotion control himself. He loves Elizabeth, but when he is torn between love and profits, after some serious thoughts, he always allows profits to win. This is vividly shown in his changing attitude to Elizabeth.

Firstly, he loves Elizabeth at the first sight. And it is clear that Elizabeth admired him also. But both of them restrains their strong emotions at that time, they have nothing and have to make a living, love is luxury to both of them, Farfrae will leave Casterbridge for his bright future, and Elizabeth is just a poor girl at that time. "When, candel in hand, she reached the 
top of the stairs on her way down again, Mr. Farfrae was at the foot coming up. She could not very well retreat; they met and passed in the turn of the staircase. She must have appeared interesting in some way---notwithstanding her plain dress---or rather, possibly, in consequence of it, for she was a girl characterized by earnestness and soberness of mien, with which simple drapery accorded well. Her face flushed, too, at the slight awkwardness of the meeting, and she passed him with her eyes bent on the candle-flame that she carried just below her nose. Thus it happened that when confronting her he smiled; and then, with the manner of a temporarily light-hearted man, who has started himself on a flight of song whose momentum he cannot readily check, he softly tuned an old ditty" [6] (64).

Secondly, Farfrae shows great interest in Elizabeth when he knows that Elizabeth is the stepdaughter of Henchard, the most powerful man in Casterbridge who is at the height of his career and enjoys a high social status. "At first, Miss Newson's beauty was not regarded with much interest by anybody in Casterbridge, Donald Farfrae's gaze, it is true, was now attracted by the Mayor's so called stepdaughter, but he was only one. The truth is that she was but a poor illustrative instance of the prophet Brauch's sly definition: The virgin that loveth to go gay... But Donald Farfrae admired her, too; and altogether the time was an exciting one; sex had never before asserted itself in her so strongly, for in former days she had perhaps been too impersonally human to be distinctively feminine" [6] (112).

Thirdly, Farfrae easily gives up his courtship over Elizabeth after Henchard indicates his displeasure over his feelings for Elizabeth. And he quickly transfers his love from Elizabeth to Lucetta. He knows exactly about the situation. He is very clear about the fact that he will never marry Elizabeth without the permission of Henchard, and he knows very well about the character of Henchard, Farfrae is a businessman to the core, he will not give up his personal profits and wastes his precious time on Elizabeth which he thinks will be futile. Though he loves Elizabeth, he will not show his love irrationally, and will never insist on courting her before the situation is ripe. He changes his attitude and decisions with the change of time and his personal profits. $\mathrm{He}$ is flexile in dealing with the relationship with everyone, including his love. He easily changes his love to Lucetta. "Poor Elizabeth-Jane, little thinking what her malignant star had done to blast the budding attentions she had won from Donald Farfrae, was glad to hear Lucetta's words about remaining" [6] (197). And Elizabeth was rather shocked and sad to see Farfrae's ignorance of her. "The next phase of the supersession of Henchard in Lucetta's heart was an experiment in calling her performed by Farfrae with some apparent trepidation. Conventionally speaking he conversed with both Miss Templeman and her companion; but in fact it was rather that Elizabeth sat invisible in the room. Donald appeared not to see her at all, and answered her wise little remarks with curtly indifferent monosyllables, his looks and faculties hanging on the woman who could boast of a more Protean variety in her phases, moods, opinions, and also principles, than could Elizabeth. Lucetta had persisted in dragging her into the circle; but she had remained like an awkward third point which that circle would not touch. Susan Henchard's daughter bore up against the frosty ache of the treatment, as she had borne up under worse things, and contrived as soon as possible to get out of the inharmonious room without being missed. The Scotchman seemed hardly the same Farfrae who had danced with her and walked with her in a delicate poise between love and friendship---that period in the history of a love when alone it can be said to be unalloyed with pain" [6] (207).

Farfrae's change of love partly took place because Lucetta is so charming and attractive that he could not turn her down, and partly because Lucetta is a rich lady who can help him in business. Farfrae is an absolute merchant who deals with everything according to his own personal interests. And he is rather rational in taking any actions. He will never do anything to his disadvantage. The flexibility of Farfrae shows that he never tries to get something that is impossible for him, and he will frequently changes his strategies to achieve his own ambition.

\section{Conclusion}

This paper tried to analyze The Mayor of Casterbridge from the conflicts between Henchard and Farfrae. The conflicts between Henchard and Farfrae dominate the novel. Henchard is an ambitious man who fights against the fate, but his tragedy is inevitable due to his stubbornness and traditional characteristics. No matter how hard he tries, he can not change his tragic ending. The contrasts between tradition and modernization are presented in the novel through the detail analysis of Henchard and Farfrae. Henchard is an old mayor from the old world, while Farfrae is a representative of the new world. Hardy firmly believes that the new world will take the place of the old one. Henchard is too stubborn to adapt himself to the changing environment, therefore, it is inevitable that he will be defeated by Farfrae and he cannot avoid his doomed failure. In the end, Henchard depart from the world, poor and lonely, master of nothing. On the contrary, Farfrae rises to the culmination of his business and gains everything once owned by Henchard, because he is flexible and willing to adapt to the changing environment, and he wins in every aspect in the novel, and become the new mayor of Casterbridge.

\section{Acknowledge}

This work is supported by Top-notch Academic Programs Project of Jiangsu Higher Education Institutions.

\section{References}

[1] Fussell D H. The maladroit delay: the changing times in Hardy's The Mayor Of Casterbridge. Critical Quarterly, 1979, 21(3): 17-30.

[2] Kramer, Dale, "Introduction" to Thomas Hardy, The Mayor of Casterbridge, Beijing: Foreign Language Teaching \& Research Press, Oxford University Press, 1994, 21-29. 
[3] Kar, Frederic R. The Mayor of Casterbridge: A New Fiction Defined, Mark Schorer, ed Modern British Fiction. New York: Oxford University Press, 1961, 27.

[4] Moynahan J. The Mayor of Casterbridge and the Old Testament's First Book of Samuel: A Study of Some Literary Relationships. Pmla, 1956, 71(1): 118-130.

[5] Laura, David J. De. The Ache of Modernism in Hardy's later Novels, ELH, 34(3), 1967

[6] Hardy, Thomas. The Mayor of Casterbridge. New York: Bantam Books Press, 1912.

[7] Gerdabi H. Characters' Names in the Shade of Literary Tendencies: An Onomastic Approach to Characters' Names in
The Mayor of Casterbridge, A Portrait of an Artist as a Young Man, and The City of Glass [J]. Interdisciplinary Literary Studies, 2017, 19.

[8] Donnelly B. THOMAS HARDY'S "THE MOCK WIFE," MAUMBURY, AND THE MAYOR OF CASTERBRIDGE [J]. Victorian Literature and Culture, 2016, 44(1): 97-110.

[9] Koehler K. 'Essentially separated in spite of all uniting factors': Thomas Hardy and the Community of Letter Writers [J]. Victorian Review, 2016, 41.

[10] Keen S. Thomas Hardy, Time and Narrative: A Narratological Approach to his Novels by Ken Ireland (review) [J]. Victorian Studies, 2016, 58. 